\title{
COMPARISON OF COBB ANGLE MEASUREMENT IN SCOLIOSIS BY RESIDENTS AND SPINE EXPERTS
}

\author{
COMPARAÇÃO DA MENSURAÇÃO DO ÂNGULO DE COBB NA ESCOLIOSE POR \\ RESIDENTES E ESPECIALISTAS EM COLUNA
}

\author{
COMPARACIÓN DE LA MEDICIÓN DEL ÁNGULO DE COBB EN LA ESCOLIOSIS \\ POR RESIDENTES Y ESPECIALISTAS EN COLUMNA
}

Rafael Ritter ${ }^{1}$, Yoshinobu Nagasse ${ }^{1}$, Iberê Ribeiro ${ }^{1}$, Clovis Yamazato ${ }^{1}$, Fabio Mastromauro de Oliveira ${ }^{1}$, René Kusabara ${ }^{1}$

1. Spine Pathology Group of the Hospital Municipal doTatuapé (Dr. Carmino Cariccheo), São Paulo, SP. Brazil

\begin{abstract}
Objective: The adolescent idiopathic scoliosis (AIS) is a spine deformity that occurs in both the coronal plane and the sagittal plane of patients between 10 and 17 years. The Cobb method is the most widely used to determine the angular value of scoliosis and it is defined as the "gold standard". The goal is to verify the reproducibility of the measured angles between orthopedic residents and spinal pathologies specialists, comparing the variability of the angles measured by professionals with greater and lesser experience. Method: A total of 10 radiographs of patients diagnosed with AIS were assessed. Radiographs were handed over to 7 orthopedists specialized in spine and 14 orthopedic residents. The measurement of the angles for each of the examiners was described using means and standard deviations and intraclass correlations were calculated, as well as the measure of repeatability, and Bland-Altman plots were designed with the results of the measurements of each group of examiners, according to experience, to assess the agreement/reproducibility of Cobb angle measurements. Results: Each examiner obtained a resulting average of 10 cases summation. In order to assess trends in variability of the measurements of the angles of each group graphs were plotted based on the arithmetic mean of each of the 10 cases by the total number of participants in the group versus the standard deviation in each case. Conclusion: There was a poor correlation (ICC $=0.4)$ in the measurement of Cobb in both groups, demonstrating difficulties in the method, which cannot be overcome by the expertise.
\end{abstract}

Keywords: Scoliosis; Spine; Comparative study; Radiography.

\section{RESUMO}

Objetivo: A escoliose idiopática do adolescente (EIA) é uma deformidade da coluna vertebral que ocorre tanto no plano coronal quanto no plano sagital de pacientes entre 10 e 17 anos. O método de Cobb é o mais utilizado para determinar o valor angular da escoliose e é definido como "padrão de referência". O objetivo é verificar se existe reprodutibilidade dos ângulos aferidos entre residentes de ortopedia e especialistas em patologias da coluna vertebral, comparando a variabilidade dos ângulos entre profissionais com maior e menor experiência. Método: Foram avaliadas 10 radiografias de pacientes com diagnóstico de EIA. As radiografias foram entregues a 7 ortopedistas especialistas em coluna e 14 residentes de ortopedia. As aferições dos ângulos de cada um dos examinadores foram descritas com uso de médias e desvios padrões e foram calculadas as correlações intraclasse, bem como a medida de repetitibilidade, e construídos os gráficos de Bland-Altman com os resultados das aferições de cada grupo de examinadores, conforme a experiência, para avaliação da concordância/reprodutibilidade das medidas do ângulo de Cobb. Resultados: Cada examinador obteve uma média resultante da somatória dos 10 casos. Com a finalidade de avaliar tendências nas variabilidades das aferições dos ângulos de cada grupo, foram elaborados gráficos baseados na média aritmética de cada um dos 10 casos pelo total de participantes do grupo versus o desvio padrão de cada caso. Conclusão: Houve uma baixa concordância $(\mathrm{CCl}=0,4)$ na aferição do Cobb em ambos os grupos, demonstrando que há dificuldades no método, que não são transponíveis com a experiência.

Descritores: Escoliose; Coluna vertebral; Estudo comparativo; Radiografia.

\section{RESUMEN}

Objetivo: La escoliosis idiopática del adolescente (EIA) es una deformidad de la columna vertebral que se ocurre tanto en el plano coronal como en el plano sagital en pacientes entre 10 y 17 años. El método de Cobb es el más ampliamente utilizado para determinar el valor angular de la escoliosis, considerado actualmente el "estándar de oro". El objetivo es verificar la reproducibilidad de los ángulos medidos entre los residentes de ortopedia y expertos en patologías de la columna vertebral, comparando la variabilidad de los ángulos entre los profesionales con mayor y menor experiencia. Método: Un total de 10 radiografías de pacientes diagnosticados con EIA fue analizado. Las radiografías fueron evaluadas por 7 ortopedistas especialistas en columna vertebral y 14 residentes de ortopedia. La medida de los ángulos de cada uno de los examinadores se describe con el uso de medias e desviaciones estándar y se calcularon las correlaciones intraclase y la repetibilidad de la medición, y los gráficos de Bland-Altman fueron diseñados con los resultados de las mediciones de cada grupo de examinadores, de acuerdo a la experiencia, para evaluar la concordancia/reproducibilidad de las mediadas del ángulo de Cobb. Resultados: Cada examinador obtuvo un promedio resultante del sumatorio de los 10 casos. Con el fin de evaluar las tendencias en la variabilidad de las mediciones de los ángulos de cada grupo, se prepararon gráficos en base a la media aritmética de cada uno de los 10 casos por el total de participantes en el grupo frente a la desviación estándar de cada caso. Conclusión: Se evidenció una concordancia baja $(\mathrm{CCl}=0,4)$ en la medición de Cobb entre ambos grupos, lo que demuestra la presencia de dificultades en el método, que no puede ser transpuesta por la experiencia.

Descriptores: Escoliosis; Columna vertebral; Estudio comparativo; Radiografía. 


\section{INTRODUCTION}

Adolescent idiopathic scoliosis (AIS) is a deformity that occurs in both the coronal and sagittal planes in patients between 10 and 17 years of age, with a higher prevalence of curves of greater magnitude in female patients. ${ }^{1}$ The incidence varies between $1 \%$ and $3 \%$ of the population. The etiology of AIS is still unknown today, being the focus of various studies attempting to better understand its possible causes. Genetic factors, abnormalities of the central nervous system, hormonal and metabolic dysfunction, and disturbances in the growth of the vertebrae have been studied. . $^{1,3,4}$

Early diagnosis of AIS and the radiographic analysis of the curve using propaedeutic maneuvers like the Adams test (Figure 1) and PA and profile radiographs of the spine (Figure 2) are fundamental to defining the conduct of the case in question. If the diagnosis is late or the analysis of the curve is incorrect, there is a greater chance for progression of the deformity. This can cause esthetic, psychological, and serious cardiorespiratory complications for the patient. ${ }^{5}$

The Cobb method ${ }^{6}$ is the most used method for determining the value of the angle of the scoliosis and is defined as the "gold standard" ${ }^{7-9}$ The angle is calculated from the projections of a line touching the upper surface of the most cranial vertebra of the curve and a line touching the lower surface of the terminal lamina of the most caudal vertebra of the curve. (Figure 3) Curves of less than $10^{\circ}$ are not considered to be scoliosis and curves greater than $40^{\circ}$ are usually considered to require surgical treatment. ${ }^{1}$ Some authors say that the method is flawed because it is susceptible to error. ${ }^{10-12}$

Standardized measurements of the Cobb angle with controls for possible errors provide better diagnostic and therapeutic conduct effectiveness. ${ }^{13}$

The objective of this study was to confirm whether there is reproducibility of the angle measurements among orthopedic residents and among spine pathology specialists, comparing the variability of the angles between professionals with more and less experience, specialists and residents, respectively

\section{CASE SERIES AND METHOD}

Ten (10) posteroanterior total spine radiographs of patients diagnosed with AIS were evaluated. The patient age ranged from 11 to 16 , with an average of 13.3 years of age. There was a predominance of female with eight patients (80\%).

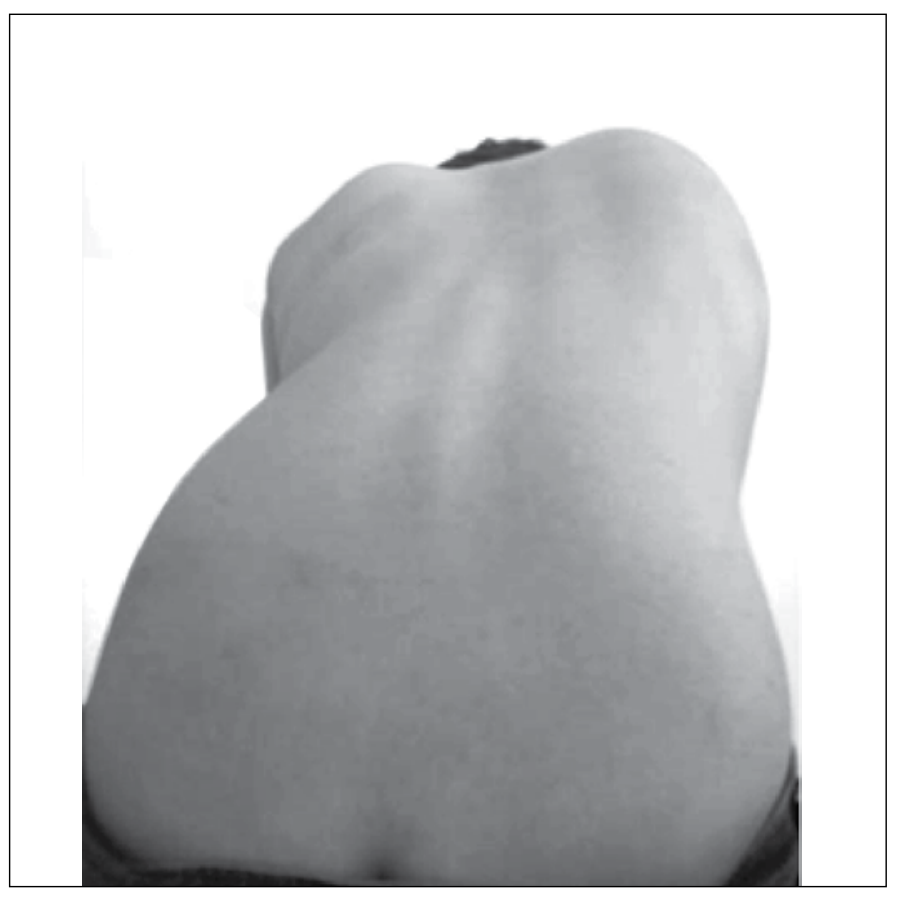

Figure 1. Adams Test, showing the gibbosity on the right.

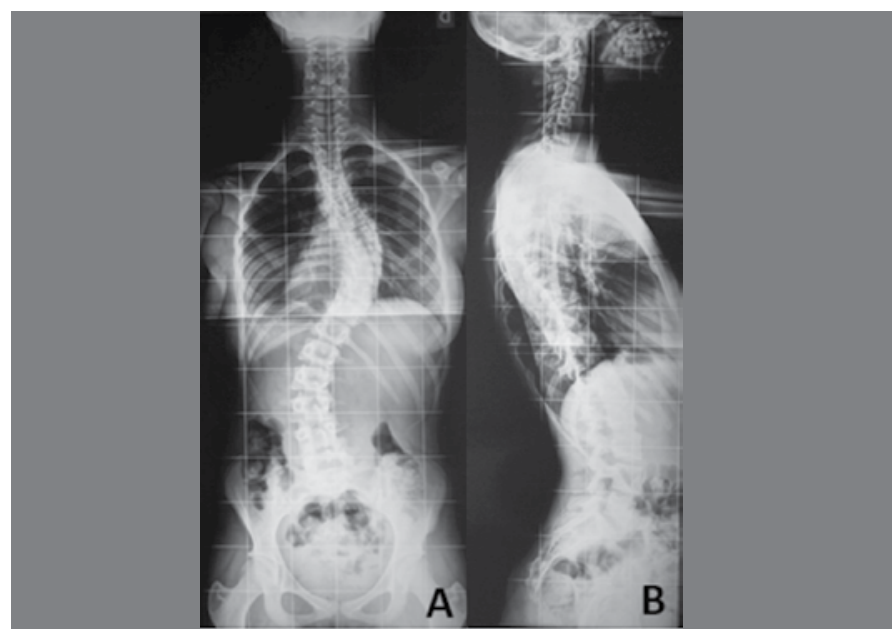

Figure 2. A - Panoramic radiograph image of the spine in PA. B- Panoramic radiograph image of the spine in lateral view.

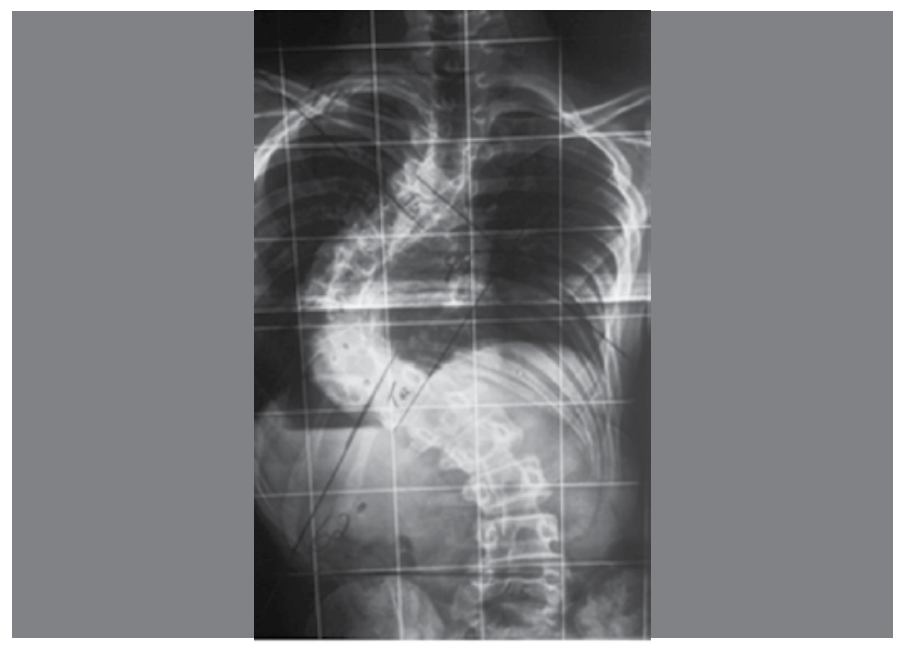

Figure 3. Measurement of the Cobb angle.

Inclusion criteria were patients without segmentation and/or vertebral formation changes, with principal curves greater than $25^{\circ}$, between 10 and 17 years of age, and who had never undergone previous surgical treatment. There was no conflict of interest in the study proposal and no need to submit the study to the Institutional Review Board.

The radiographs were printed and delivered to seven spine specialists, each with between 5 and 20 years of experience, and to 14 orthopedics and traumatology residents with from one to two years of training. A class on the method of measuring the Cobb angle, including practical training, was given for the residents. All the measurements were performed with the same type of goniometer in order to avoid measurement errors because of instrument imperfections.

The terminal vertebrae of the scoliotic curves were determined according to the criteria of the study participants. The terminal vertebrae are defined by the Scoliosis Research Society (SRS) as the most tilted vertebrae of a scoliotic curve. ${ }^{14}$

The measurements of the angles taken by each of the examiners were described using averages and standard deviations and the intraclass correlations were calculated with 95\% confidence intervals, ${ }^{15}$ as well as the measure of repeatability, which estimates measurement errors among the evaluators. Bland and Altman ${ }^{16}$ graphs were constructed with the results of the Cobb angle measurements for each group of examiners according to experience, residents and specialists, in order to evaluate the concordance/ reproducibility of the Cobb angle measurements. 
The variability between the groups of examiners and the standard deviation were calculated for each of the radiographs and the variability within each group of examiners was described using averages and standard deviations. Then the groups of examiners were compared in terms of the variability of the measurements using the paired Student's t-test. ${ }^{7}$

The test was performed with a level of significance of $5 \%$.

\section{RESULTS}

After analyzing the data, each examiner obtained an average resulting from the sum of the ten cases, displayed in Table 1.

In order to evaluate trends in the variability of the angle measurements in each group, graphs were prepared based on the arithmetic average of each of the 10 cases for all participants in the group versus the standard deviation of each case (Figures 4 and 5).

Table 2 represents the variability within each group of examiners using the averages and standard deviations resulting from each case.

\section{DISCUSSION}

According to the SRS, the Cobb method continues to be the gold standard for determining the values of scoliotic curves..$^{7-9,14}$ It has the advantage of higher sensitivity for curve progressions and post-operative assessments. ${ }^{14}$

According to the literature, the method has a low level of reproducibility and angle variations between $5^{\circ}$ and $10^{\circ}$. The

Table 1. Description of the angles measured by each examiner and the concordance/reproducibility results within each group of examiners according to experience.

\begin{tabular}{|c|c|c|c|c|c|c|}
\hline \multirow{2}{*}{ Examiner } & \multirow{2}{*}{ Average } & \multirow{2}{*}{ SD } & \multirow{2}{*}{$\mathrm{CIC}$} & \multicolumn{2}{|c|}{$\mathrm{Cl}(95 \%)$} & \multirow{2}{*}{ Repeatability } \\
\hline & & & & Lower & Upper & \\
\hline 1 & 45.70 & 12.18 & \multirow{14}{*}{0.422} & \multirow{14}{*}{0.226} & \multirow{14}{*}{0.726} & \multirow{14}{*}{7.31} \\
\hline 2 & 43.50 & 9.14 & & & & \\
\hline 3 & 45.00 & 9.61 & & & & \\
\hline 4 & 45.50 & 8.40 & & & & \\
\hline 5 & 45.30 & 11.25 & & & & \\
\hline 6 & 44.90 & 11.11 & & & & \\
\hline 7 & 44.80 & 12.22 & & & & \\
\hline 8 & 51.20 & 6.36 & & & & \\
\hline 9 & 49.30 & 8.69 & & & & \\
\hline 10 & 46.50 & 9.58 & & & & \\
\hline 11 & 45.10 & 9.79 & & & & \\
\hline 12 & 49.40 & 8.59 & & & & \\
\hline 13 & 51.20 & 6.36 & & & & \\
\hline 14 & 45.10 & 9.79 & & & & \\
\hline 1 & 48.20 & 9.50 & \multirow{7}{*}{0.417} & \multirow{7}{*}{0.189} & \multirow{7}{*}{0.735} & \multirow{7}{*}{7.21} \\
\hline 2 & 47.50 & 11.31 & & & & \\
\hline 3 & 46.90 & 9.21 & & & & \\
\hline 4 & 51.50 & 8.72 & & & & \\
\hline 5 & 45.50 & 10.12 & & & & \\
\hline 6 & 52.60 & 9.25 & & & & \\
\hline 7 & 39.00 & 11.40 & & & & \\
\hline
\end{tabular}

SD: standard deviation; CIC: coefficient of intraclass correlation; Cl: confidence interval. problems result from variations in goniometers, the difficulty in visualizing the vertebral plateau, and, above all, from poor selection of the terminal vertebrae. ${ }^{14,18}$

Most authors define progression as an increase of $5^{\circ}$ or more assessed by the Cobb measurement technique over two or more visits. Accurate measurement is critical, as variability greater than $5^{\circ}$ can mask the progression of a curve or result in a poor therapeutic indication. ${ }^{8}$

Our case series agreed with the literature data. Table 1 shows that the concordances of the groups of examiners were quite close $(\mathrm{CIC}=0.422$ for the residents and $\mathrm{CIC}=0.417$ for the specialists) and the repeatability, which is the estimate of error among the evaluators, was approximately $7^{\circ}$ for each group of examiners. The similar, low CIC values among the groups shows that the method has low reproducibility, regardless of the experience of the examiner. It should be noted that the specialists did not attend to the explanation of the Cobb method measurement technique.

Figures 4 and 5 do not suggest any trend in the variability between the Cobb angle measurements, either for the residents

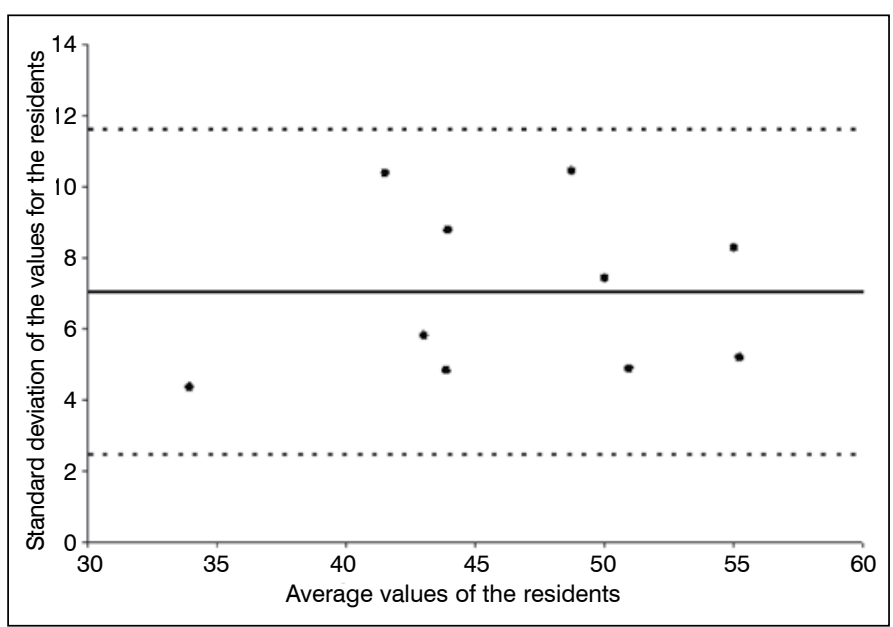

Figure 4. Bland-Altman of the Cobb angles for the residents.

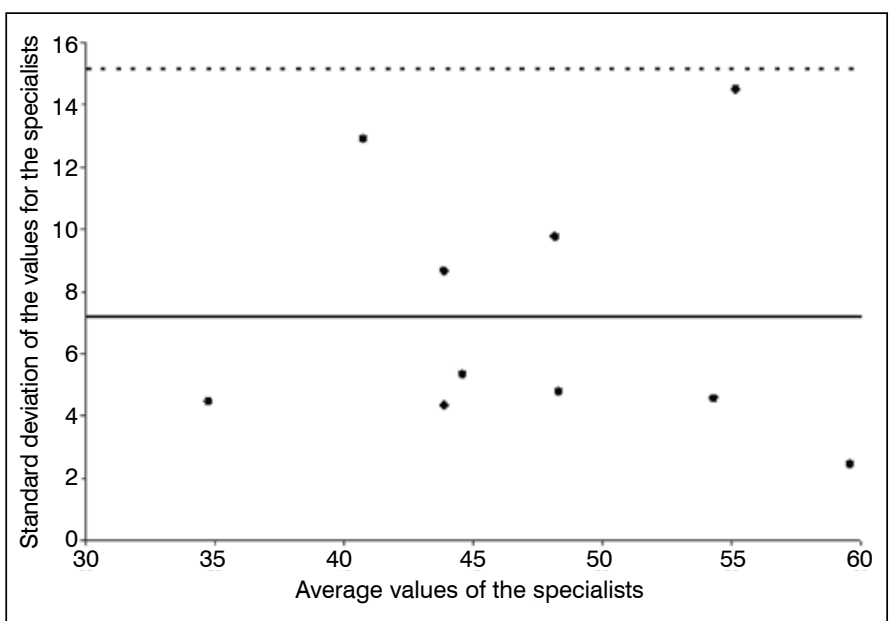

Figure 5. Bland-Altman of the Cobb angles for the specialists.

Table 2. Description of variability between the groups of examiners according to experience and results of comparison test between the groups.

\begin{tabular}{c|c|c|c|c}
\hline Variable & Average & SD & \multicolumn{2}{|c}{} \\
\cline { 1 - 4 } Variability of the residents & 7.06 & 2.34 & 10 & \multirow{2}{*}{0.003} \\
\cline { 1 - 4 } Variability of the specialists & 7.18 & 4.08 & 10 & \\
\hline
\end{tabular}


or for the specialists. Nor was there an increase in variability in accordance with the increase in the angle values, characterizing a curve without trends.

We observed a slightly greater variation among the measurements taken by the specialists than those of the residents, but the difference was small compared to the approximately $7^{\circ}$ of variation between one evaluator and another. (Table 1)

Table 2 shows that the average variability of the residents and the specialists were statistically equal $(p=0.903)$ and, as already estimated by the measure of repeatability (Table 1 ), this variability is approximately $7^{\circ}$.

The results show that the CICs are similar, which would correspond to the experience of the examiner not influencing the results.
However, there are reports that skill in measuring improves with practice, increasing the accuracy of the method. ${ }^{4,17}$

\section{CONCLUSION}

There was low concordance $(\mathrm{ClC}=0.4)$ in the Cobb measurements in both groups, showing that there are difficulties with the method and that they do not depend on the experience.

All authors declare no potential conflict of interest concerning this article.

AUTHOR CONTRIBUTIONS: Each author made significant, individual contributions to the development of this manuscript. RR, YN, and RK were responsible for writing the text, as well as the development of the thesis and the statistical analysis of the proposed study; IR, $\mathrm{CY}$, and FMO researched the biographical references and edited the final version of the text.

\section{REFERENCES}

1. Newton PO, Wenger DR. Escolioses idiopática e congenital. In: Lovell WW, Winter RB, Morrissy RT, Weinstein SL. Ortopedia pediátrica 5a. ed. Barueri, SP: Manole; 2005. p. 737-806.

2. Velezis MJ, Sturm PF, Cobey J. Scoliosis screening revisited: findings from the District of Columbia. J Pediatr Orthop. 2002;22(6):788-91.

3. Defino HLA. Herrero F, Costa HRT. Escoliose idiopática. In: Pudles E, Defino HLA. A coluna vertebral: conceitos básicos. São Paulo, SP: Artmed; 2014. p. 183-203.

4. Wajchenberg M, Lazar M, Cavaçana N, Martins DE, Licinio L, Puertas EB, et al. Genetic aspects of adolescent idiopathic scoliosis in a family with multiple affected members: a research article. Scoliosis. 2010:5:7.

5. Godinho RRS, Ueta RHS, Curto DD, Martins DE, Wajchenberg M, Puertas EB. Mensuração da curva escoliótica pela técnica de cobb intraobservadores e interobservadores e sua importância clínica. Coluna/Columna. 2011;10(3):216:20.

6. Cobb J. Outline for the study of scoliosis; Instr Course Lect. 1948;5:261.

7. Mehta SS, Modi HN, Srinivasalu S, Chen T, Suh SW, Yang JH, Song HR. Interobserver and intraobserver reliability of Cobb angle measurement: endplate versus pedicle as bony landmarks for measurement: a statistical analysis. J Pediatr Orthop. 2009;29(7):749-54.

8. Gstoettner M, Sekyra K, Walochnik N, Winter P, Wachter R, Bach CM. Inter- and intraobserver reliability assessment of the Cobb angle: manual versus digital measurement tools. Eur Spine J. 2007;16(10):1587-92.

9. De Carvalho A, Vialle R, Thomsen L, Amzallag J, Cluzel G, le Pointe HD, et al. Reliability analysis for manual measurement of coronal plane deformity in adolescent scoliosis. Are
$30 \times 90 \mathrm{~cm}$ plain films better than digitized small films? Eur Spine J. 2007;16(10):1615-20. 10. He JW, Yan ZH, Liu J, Yu ZK, Wang XY, Bai GH, et al. Accuracy and repeatability of a new method for measuring scoliosis curvature. Spine (Phila Pa 1976). 2009;34(9):E323-9.

11. Allen $\mathrm{S}$, Parent $\mathrm{E}$, Khorasani M, Hill DL, Lou E, Raso JV. Validity and reliability of active shape models for the estimation of cobb angle in patients with adolescent idiopathic scoliosis. J Digit Imaging. 2008;21(2):208-18.

12. Sperandio FF, Tavares GMS, Santos GM. Reprodutibilidade intra e interobservadoresno ângulo de Cobb em indivíduos escolióticos. Rev Bras Cresc Desenv Hum.2011;21(1):21-9.

13. Modi HN, Chen T, Suh SW, Mehta S, Srinivasalu S, Yang JH, et al. Observer reliability between juvenile and adolescent idiopathic scoliosis in measurement of stable Cobb's angle. Eur Spine J. 2009;18(1):52-8.

14. Stokes IA, Aronson DD, Ronchetti PJ, Labelle H, Dansereau J. Reexamination of the Cobb and Ferguson angles: bigger is not always better. J Spinal Disord. 1993;6(4):333-8.

15. Fleiss JL. The design and analysis of clinical experiments. New York: Wiley; 1986.

16. Altman DG, Bland JM. Measurement in medicine: the analysis of method comparison studies. Statistician. 1983;32(3):307-17.

17. Kirkwood BR, Sterne JAC. Essential medical statistics. 2nd ed. Massachusetts, USA: Blackwell Science; 2006.

18. Wright JG, Feinstein AR. Improving the reliability of orthopaedic measurements. J Bone Joint Surg Br. 1992;74(2):287-91. 